\title{
REVITALIZATION OF MESATUA BALI CULTURE THROUGH THE DIGITAL MEDIA
}

\author{
I Gede Yudha Pratama
}

\author{
Postgraduate Faculty Design Master's Study Program \\ Universitas Komputer Indonesia
}

Jl. Dipatiukur No. 112-116, Bandung, Jawa Barat 40132

Email: igedeyudhap@gmail.com

\begin{tabular}{|c|c|}
\hline Received: $\mathrm{n} / \mathrm{a}$ & Revised: n/a \\
\hline Editor: Abay D Subarna & Reviewer: n/a \\
\hline
\end{tabular}

\begin{abstract}
This research was compiled based on a visual design study on the revitalization of the Mesatua Bali culture which was divided into 3 (three) periods, namely: the first Balinese Mesatua (oral) culture, the second period Mesatua Balinese culture (written literature), and the third period Mesatua Bali culture (digital visual). The Mesatua Bali culture is an oral tradition culture carried out by parents to their children. In this study begins by sharpening the substance and structure of research problems designed through the structure of the thinking of researchers. The design of the structure of thought focuses on the purpose of research, namely, to find out the causes and consequences of changes in the revitalization of Balinese Mesatua culture. The method used in this study is descriptive qualitative method, in order to meet objective data needs in conducting studies on the revitalization of Balinese Mesatua culture, this study uses data collection techniques through observation, interviews, and documentation. Surgery for object research is carried out starting from observing aspects of actors, technology and targets. Furthermore, an analysis of the stimuli generated starting from space, time and atmosphere (desa-kala-patra) and the human sensory field. In the final stage a study of visual elements in visual objects is carried out starting from the composition of balance, continuity, combination, unity, typography to color. Then it is compared based on each period of the object of research with 3 (three) levels of values, namely, essential, important, and desirable to analyze aspects that influence the revitalization of the Balinese Mesat culture and dissect what are new, what remains, what was lost, and what changed from the 3 (three) periods to the revitalization of the Balinese Mesatua culture. The results of this study indicate that there is a phenomenon of change in each period from the revitalization of Balinese Mesatua culture. The phenomenon of changes occurring in the revitalization of the Balinese culture from oral to become a visual form (design) is influenced and dilaterbelak by several factors, namely: factors of actors, target factors, technological factors along with factors of space, time, atmosphere (desa-kala-patra) different in each period.
\end{abstract}

Keywords: Cultural Revitalization, Visual Design, Mesatua Bali, Digital Media, Visual Digital, Phenomenon of Change.

Abstrak. Penelitian ini disusun berdasarkan studi desain visual pada revitalisasi budaya Mesatua Bali yang dibagi menjadi 3 (tiga) periode, yaitu: budaya Mesatua Bali (lisan) pertama, periode kedua budaya Bali Mesatua (literatur tertulis), dan periode ketiga budaya Mesatua Bali (digital visual). Budaya Mesatua Bali adalah budaya tradisi lisan yang dilakukan oleh orang tua kepada anak-anak mereka. Dalam penelitian ini dimulai dengan mempertajam substansi dan struktur masalah penelitian yang dirancang melalui struktur pemikiran peneliti. Desain struktur 
pemikiran berfokus pada tujuan penelitian, yaitu, untuk mengetahui penyebab dan konsekuensi dari perubahan revitalisasi budaya Mesatua Bali. Metode yang digunakan dalam penelitian ini adalah metode deskriptif kualitatif, dalam rangka memenuhi kebutuhan data obyektif dalam melakukan penelitian revitalisasi budaya Mesatua Bali, penelitian ini menggunakan teknik pengumpulan data melalui observasi, wawancara, dan dokumentasi. Pembedahan untuk objek penelitian dilakukan mulai dari mengamati aspek aktor, teknologi dan target. Selanjutnya, analisis rangsangan yang dihasilkan mulai dari ruang, waktu dan atmosfer (desa-kala-patra) dan medan sensorik manusia. Pada tahap akhir studi elemen visual pada objek visual dilakukan mulai dari komposisi keseimbangan, kontinuitas, kombinasi, kesatuan, tipografi hingga warna. Kemudian dibandingkan berdasarkan pada setiap periode objek penelitian dengan 3 (tiga) tingkatan nilai, yaitu esensial, penting, dan diinginkan untuk menganalisis aspek-aspek yang mempengaruhi revitalisasi budaya Mesat Bali dan membedah apa yang baru, apa yang tersisa., apa yang hilang, dan apa yang berubah dari 3 (tiga) periode menjadi revitalisasi budaya Mesatua Bali. Hasil penelitian ini menunjukkan bahwa ada fenomena perubahan di setiap periode dari revitalisasi budaya Mesatua Bali. Fenomena perubahan yang terjadi dalam revitalisasi budaya Bali dari lisan menjadi bentuk visual (desain) dipengaruhi dan dilaterbelak oleh beberapa faktor, yaitu: faktor aktor, faktor target, faktor teknologi beserta faktor ruang, waktu, suasana (desakala-patra) berbeda di setiap periode.

Kata kunci: Desain Visual; Fenomena Perubahan; Media Digital; Mesatua Bali; Revitalisasi Budaya.

\section{INTRODUCTION}

Bali is always known for its rich culture and various traditions. One of the traditional cultures is "Mesatua Bali" (Storytelling), as an ancestral heritage that contains educational values and messages of wisdom norms. The Mesatua tradition culture in Bali is now starting to be popular again and is known after so long eroded by the wheel of the digital age or gadget. Since the development of the digital era, it has been very rare for parents to apply the Mesatua Bali tradition to children. So with this digital development, there is an effort to revitalize the Mesatua Balinese traditional culture which was originally an oral culture (audio), then developed in written literary works (text) and now the Mesatua Bali culture is being reintroduced through the use of digital technology that is packaged in stories. image (visual), this made oral Mesatua Bali culture evolve into digital audio visual. Departing from this cultural revitalization, this study aims to conduct a visual design study on the revitalization of Balinese Mesatua culture through digital media.

Diversity is beautiful, but it needs cultural resilience to reduce the forces that arise as a result of diversity. If diversity is seen as a difference, it can lead to cultural domination which in turn will lead to a cultural clash. According to Hobsbawm (1992), the most important thing in understanding cultural diversity as production and reproduction is in the process, namely formalization, ritualization and characterization that refers to the past. Perhaps, for the older generation, the revitalization of local culture is not necessarily acceptable, so the process of adaptation is still ongoing, because evoking local cultural values is a response to the dynamics of growing cultural diversity, as well as parts of the process of reformulating self-identity and strategies for dealing with valuable changes philosophical and historical [1]. Therefore, revitalization as a capital of cultural resilience is the main method to avoid cultural clashes.

Cultural revitalization is intended as an effort to preserve in searching, reviving or reviving local cultural values which may be a lot of deviations among adherents of culture, these deviations can be viewed from a religious, social, educational, economic and community perspective, so that the existence of culture the local does not only benefit one party on the one hand, but is still related and beneficial to the other side (Figure 1). This is because local culture is wealth and also the identity of a nation. Revitalizing local cultural traditions is basically a preservation effort in its old context with traditions in the present context. In other words it is an act of reviving a thing 
that was previously powerless to be important, or some parts are maintained and others are actualized so that it is different from the old form [2].

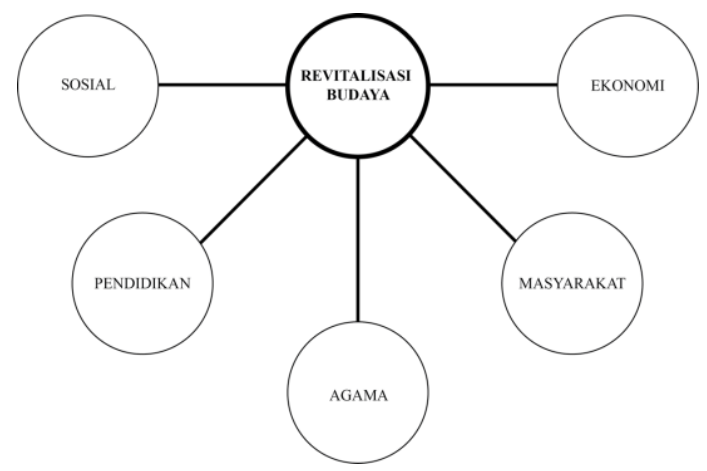

Figure 1. Photograph image of Scope of Object Study Cultural Revitalization

Ode (2015) stated that, "The values of local culture in Indonesia are priceless national assets" [3]. Local culture emerges from generation to generation and there is a deep meaning behind its appearance. "Local wisdom is one source of knowledge (culture) of society, existing in tradition and history, in formal and informal education, art, religion, and other creative interpretations" [4]. Almost every community has its own local wisdom [5]. According to Azra (2002: 209) "that local wisdom can be used as a socio-cultural mechanism contained in the traditions of Indonesian society. This tradition is believed and has proven to be a powerful means of fostering brotherhood and solidarity between citizens who have institutionalized and crystallized in social and cultural order [6].

One of Bali's local cultures that experienced revitalization is the Balinese Mesatua culture (storytelling). Mesatua Bali is an oral tradition carried out by parents to their children, which will be seen from the child's daily behavior, especially coupled with a speaking style that is well received by children, there is a response from them, it will affect their mental ability to dissect well and bad. Mesatua Bali generally uses the language of instruction in the Balinese language [7]. Along with the development of the times, children today, must be often given stories that can arouse their awareness of the importance of love for others and other creatures [8].

Satua (fairy tale) is one of the oral folktales in Bali. When associated with the science of folklore, satua belongs to the group of oral folklore. Definitely, folklore is part of a culture of a collective, which is spread and passed down from generation to generation. Folklore can be classified into three groups, oral folklore, partially oral folklore, not oral folklore. Oral folklore is a folklore whose form is purely oral, which is included in this form, namely folk language, traditional expressions, traditional questions, folk poetry and poetry, folk prose stories, and folk songs. Partial oral folklore is folklore which is a mixture of verbal and non-verbal elements, which are included in this form, namely people's beliefs and folk games. Non-oral folklore is folklore which is not an oral form even though the method of making is done orally. Non-oral folklore is divided into two groups, namely material and non-material. Which includes material namely folk architecture and handicrafts of the people, as well as those included in non-material namely traditional gestures, sound signals such as kulkul and gamelan [9]. So that the one and the Mesatua Bali culture can be classified into groups of oral folklore.

With the extent of the scope of the study in research problems, this study will be limited to the scope of the study (Figure 2). The limitations of the study are described as follows:

1.From the period of the object of study, it is limited to 3 periods, starting from the revitalization of the first Balinese Mesatua (oral) culture, the second period of Mesatua Bali (book literature, 1993 -2017), the third period of Mesatua Bali (digital visual, 2017-2018). 


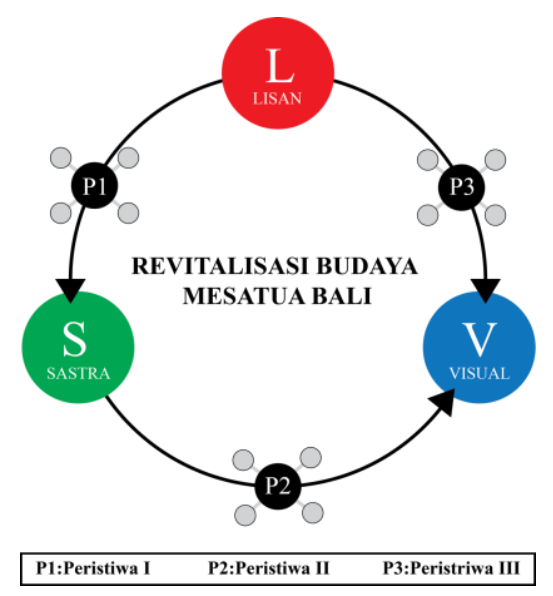

Figure 2. Photograph image of Scope of Object Study Scheme

2. From the aspect of the subject of research, which is limited only to the aspects of actors, technology, targets and village-time stimuli (space-time-atmosphere) and the human sensory field in the phenomenon of revitalsation of the Mesatua Bali culture, which is limited to the first period (oral), the second period of the Balinese Mesatua culture (book literature, 19932017), the third period of Mesatua Bali (digital visual, 2017-2018) (Figure 3).

3 . From the indicator of the phenomenon of change, it consists of 4 indicators namely; From the indicator of the phenomenon of change, it consists of 4 indicators namely; what's new? what's fixed? what's missing? what's changed? in the phenomenon of revitalsation of the Mesatua Bali culture, starting from the first period (oral), the second Mesatua Bali culture (book literature, 1993-2017), the Mesatua Bali period (third digital visual, 2017-2018) (Figure 4).

4. From the aspect of research time, it began to be examined from the first Balinese Mesatua culture (oral), the second Mesatua Bali culture (book literature, 1993-2017), the Mesatua Bali period (third visual digital, 2017-2018).

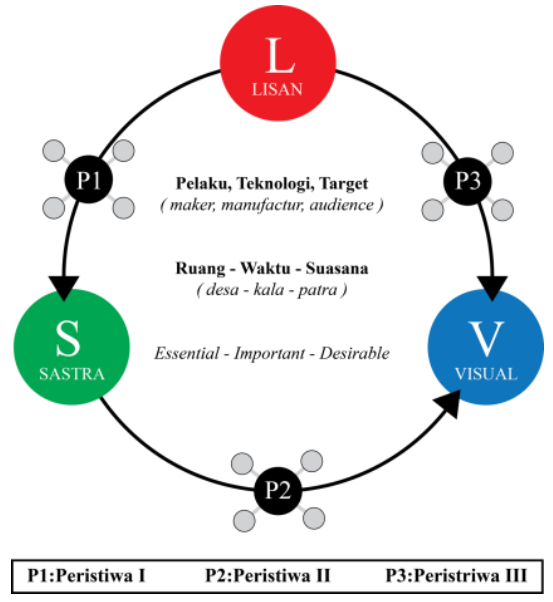

Figure 3. Photograph image of Schema Scope of Study Subjects 


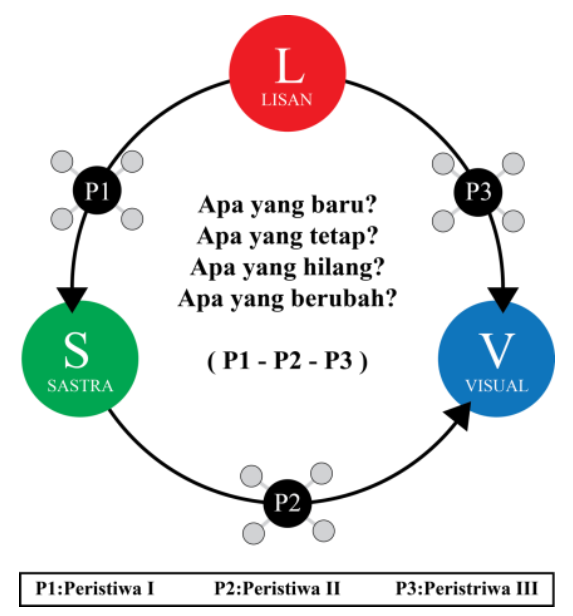

Figure 4. Photograph image of Scope of Study Indicator Scheme

\section{METHOD}

This research was conducted using qualitative research methods. This is based on the nature of the data to be produced, which is descriptive in terms of how different visual representations are generated from the visualization of Balinese Mesat culture on Instagram social media. In general, this research is a research in design that makes the visualization of Mesatua Bali culture as the object of study and revitalization of Mesatua Bali culture as a research case study in order to produce a description of an in-depth understanding of the visualization of Balinese Mesatuan culture. Understanding is obtained by analyzing and interpreting research data so that the approach used is a qualitative approach.

This research is included in the type of qualitative descriptive research. Descriptive research is research that aims to describe and interpret the object under study in accordance with the actual situation. Research using a qualitative approach will produce descriptive data in the form of written or oral words from the subject and object observed [10]. According to Sugiyono (2005) Qualitative research examines participant perspectives with strategies that are interactive and flexible. Qualitative research is intended to understand social phenomena from the perspective of participants. Thus the meaning or understanding of qualitative research is research that is used to examine the condition of natural objects where the researcher is a key instrument [11]. According to Sukmadinata (2005) the basis of qualitative research is constructivism which assumes that reality is plural, interactive and an exchange of social experiences interpreted by each individual [12]. Qualitative researchers believe that truth is dynamic and can be found only through reviewing people through their interaction with their social situation [13].

Denzin and Lincoln (2009: 2) reveal that a qualitative approach is an approach that focuses attention with a variety of methods, including interpretive and naturalistic approaches to the subject of the study. In qualitative research, researchers study objects in their natural context, try to understand or interpret phenomena that are seen from the side of meaning attached to humans (researchers) to him. That is, in the context of this thesis research, his presentation was presented qualitatively by describing the results of the study in accordance with the findings in data analysis [14]. According to Sachari (2005), to review a design phenomenon tends to use multidisciplinary with a variety of different scientific approaches, because approaches through one discipline with observers who focus on objects or even certain components are considered less meaningful. So to describe design phenomena above, a dynamic and rich phenomenon is used in a multidisciplinary approach which is considered the most meaningful [15].

The main approach used in this study is an aesthetic approach related to the phenomenon of change. This approach was chosen because it has relevance to the problems related to the 
changes that occur in each object in each period of revitalization of the Balinese Mesatua culture.

As the foundation of object surgery, visual analysis is carried out by dissecting the phenomena of artifacts studied in the revitalization of the Mesatua Bali culture which is divided into 3 (three) periods, namely: the first Balinese Mesatua (oral) culture, the second Balinese Mesatua culture (book literature, 1993 - 2017), Mesatua Bali, third period (digital visual, 2017-2018). Surgery is performed on visual elements in visual objects ranging from the composition of balance, continuity, combination, unity, typography to color. The purpose of visual analysis is to find out aspects that drive changes in the revitalization of the Mesatua Bali culture from the oral period, book literature, and digital visual.

\section{RESULT AND DISCUSSION}

The discussion in this study explains the analysis and results of data from interviews, observations, and the stages carried out in the process of visual analysis in this study based on the revitalization of the Mesatua Bali culture which is divided into 3 (three) periods, namely: Balinese Mesatua culture the first period (oral), the second period of the Balinese Mesatua culture (book literature, 1993-2017), the third period of Mesatua Bali (digital visual, 2017-2018). Then this research continued to the division of aspects contained in the revitalization of the Balinese Mesatua culture as a sample, based on data sourced from sources, including, actors, targets and technology. After the selection of aspects found in the revitalization of Balinese Mesatua culture. The next stage is to describe the stimulus produced from the village (space), time (time), patra (atmosphere) along with the field of human senses in each period of phenomenon events in the revitalization of the Mesatua Bali culture, then compared based on each period of objects with 3 ( three) the level of value stated by WH Mayal developed by Dr. Joedawinata's Ahadiat, namely, essential, important, and desirable, is related to indicators of the phenomenon of change [16].

A. Analysis of Aspects of the Revitalization of the Balinese Culture of Bali (Maker - Technology - Targets)

\section{1) Phenomenon I (Oral - Literary Writing)}

At the first (first) event, the revitalization of Balinese Mesat culture from oral to visual literature was very influential on the 3 aspects above, including actors, technology and targets in each period. In Bali, the first period (oral) made parents as the main actors in Mesatua Bali, the parents delivered fairy tales (satua) verbally through narration and the local songs in Balinese songs with pupuh-pupuh starting from pupuh ginada, pupuh ginanti, pupuh pucung, pupuh sinom to pupuh semarandana and others that are unique and interesting to be inserted in every part of the Mesatua Bali style which is done by parents and grandparents in their hoarse voice that seems to be able to bring imaginative children.

Unlike the second period of Balinese culture (book literature), the role of parents as perpetrators in the previous period was helped and almost replaced by teachers in the school by reading the contents of the fairy tale (satua) contained in Satua Bali books and school teaching materials. This condition is felt in big cities and has also penetrated into the countryside. Parents seemed to have no time for the Messiah. The Messiah is also considered to be incompatible with the times. Even more tragic, it is stated that the Messatua is an ancient way of educating children that must be abandoned.

This is because most parents provide the widest opportunity for their children to watch television and play videos and play play stations. Even though in Bali, there are many cultural values which are very high and universally applicable. One of the cultural values is positive behavior in an effort to preserve the environment as mandated by the Pancasila of the Republic of Indonesia.

2) Phenomenon II (Digital Visual Literature) 
In the second (second) event, the revitalization of the Balinese Mesatua culture from written literature to visual digital was very influential on the 3 aspects above, including actors, technology and targets in each period.

The beginning of the second period of revitalization of the Balinese culture of Bali (book literature) Some book writers, collecting stories of Balinese folklore (satua) with the aim of introducing and disseminating the story of Bali's satua, besides wanting to reap content that mostly refers to education and entertainment, especially for children.

With the spread of the Balinese Satua book, the hopes can be utilized and enjoyed by students and students, and they have no difficulty in getting story material which at that time was a school assignment from the teachers of the Balinese language.

After the second period of progress came the efforts to revitalize and preserve Mestua Bali by following the current technological developments. Some satua published in satua books began to be revitalized through visualization of storytelling images by the Katur Nusantara community and loaded into social media intagram, this visualization is better known as the term pictorial (cergam). This is where the changes seen from the actors who at first were parents and teachers are now illustrators and designers who present Mesatua Bali culture with pictures telling stories through digital visuals which are packaged in several pages in a fairy tale title (satua). Likewise, the target of digital visuals that are developing at this time makes the increase in the coverage of the intended target which was previously only children now increasing the target of the wider community.

3) Phenomenon III (Oral - Digital Visual)

In the third event (third), the revitalization of the Balinese Mesat culture from oral to visual digital was very influential on the 3 aspects above, including actors, technology and targets in each period. The discovery of modern technology that is sophisticated, effective, efficient and practical greatly influences the pattern of human life which demands inner and outer well-being. Communities live in situations and atmosphere to compete and race against time. Such a situation threatens the disappearance of the Mesatua (storytelling) cultural tradition in the household which is colored by a recreational atmosphere, two-way communication, and intimate relations within the family environment. Admittedly, the cultural tradition of Mesatua Bali (storytelling) which is full of moral values and character education is still needed.

The extinction of the Mesatua tradition in Bali made a loss of traditional culture that has cultural values that are very important for children. Where culture in a nation is a treasure that is priceless, without the culture of a nation will be looked down on by other nations. And culture is an inheritance from our ancestors or ancestors that is priceless. Preserving traditional culture is not only the interests and responsibilities of the government, but also the obligations of all levels of society. The importance of maintaining the existing culture, because the entry of foreign cultures into Indonesia began. The lack of filtering of foreign cultures that entered Indonesia made the culture in Indonesia begin to wear off. As a nation and people of Indonesia, they should also be aware of the importance of the form of a culture. Not only understanding, but from now on try to preserve the cultures that exist in Indonesia. The reality of children's lives today is very influential in the preservation of traditional culture, less interest in things that smell of tradition and culture. Everything related to traditional culture is considered oldfashioned, out of date and only belongs to the previous generation. In essence traditional culture as the original product of the ancestors contained many noble values forming the national identity. The young generation as a very important element and cannot be replaced with anything in preserving culture must realize the importance of preserving traditional culture. It will indeed be difficult to start, but starting from small things, the love of the homeland and culture of the Indonesian nation will grow because culture does not emerge itself but culture exists because it is passed down from generation to generation and as a young generation must preserve its culture so that the country can be recognized by other countries and Indonesian culture is not claimed by other countries, because it is not easy to preserve the existing culture [17]. 
The effort to revitalize the Mesatua Bali culture to revive the mesatua oral tradition seems far less than the writing tradition. Mesatua which used to be oral, will now be more effective and interesting if copied into illustrated stories, and will be even more interesting if presented in digital media. Interestingly, a pictorial story is very influential on children's reading and reading interests, with illustrated stories made by the Katur Nusantara community trying to display visuals that can deliver children's imagination into a story that is published.

Figure 5 is a comparafftive graph of the results of the analysis of revitalization of the Mesatua Bali culture in thefffff first period (oral), the second Mesatua Bali culture (book literature), the third Mesatua Bali (visual digital) based on the period of time which begins by identifying 3 (three) aspects, each actors, technology, and targets. The review of these aspects, namely:

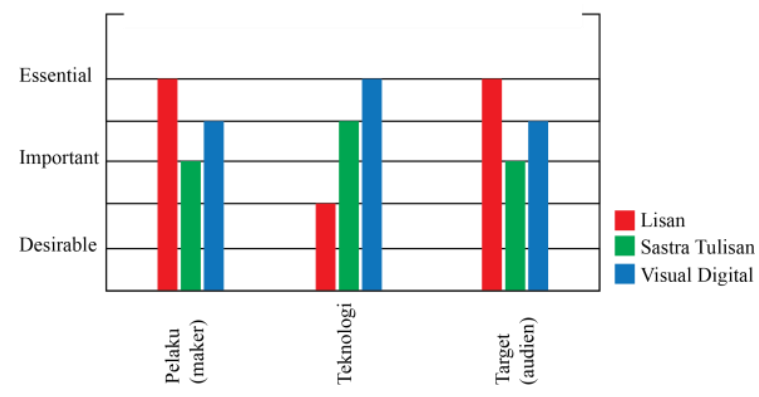

Figure 5. Photograph image of 3 Phenomenon Comparison Chart Revitalization of the Bali Mesatua Culture

After identification of the object of research, namely the revitalization of Bali's first period (oral) culture, the second period of Mesatua Bali culture (book literature), the third period of Mesatua Bali (visual digital), then the results of identification data will be analyzed as comparative data in the table then, using 4 (four) indicators of change based on time as seen on Table 1, as follows:

\begin{tabular}{|l|l|l|l|}
\hline INDICATOR & \multicolumn{1}{|c|}{ STORYTELLING } & \multicolumn{1}{|c|}{$\begin{array}{c}\text { WRITING } \\
\text { LITERATURE }\end{array}$} & \multicolumn{1}{|c|}{ VISUAL DIGITAL } \\
\hline What's new & $\begin{array}{l}\text { Mesatua Bali as an oral } \\
\text { culture delivered with } \\
\text { narration and song. }\end{array}$ & $\begin{array}{l}\text { Mesatua Bali as a literary } \\
\text { work published in print } \\
\text { media in the form of books. }\end{array}$ & $\begin{array}{l}\text { Mesatua Bali is presented } \\
\text { in the form of picture } \\
\text { telling with digital } \\
\text { visuals. }\end{array}$ \\
\hline What changed & $\begin{array}{l}\text { Parents as the main actors in } \\
\text { Mesatua Bali in the home } \\
\text { environment. }\end{array}$ & $\begin{array}{l}\text { Teachers in schools are the } \\
\text { main actors in reading Bali's } \\
\text { satua books. }\end{array}$ & $\begin{array}{l}\text { Community, illustrators } \\
\text { and designers as actors in } \\
\text { their visualization. }\end{array}$ \\
\hline What is missing & $\begin{array}{l}\text { Conversation of parents with } \\
\text { children in the Messatua that } \\
\text { fosters children's } \\
\text { imagination. }\end{array}$ & $\begin{array}{l}\text { Children are rarely able to } \\
\text { do Mesatua Bali activities at } \\
\text { home. }\end{array}$ & $\begin{array}{l}\text { Reduced imagination of } \\
\text { children or targets, } \\
\text { because images have been } \\
\text { presented. }\end{array}$ \\
\hline What's fixed & $\begin{array}{l}\text { Children as the main target } \\
\text { in Mesatua Bali. }\end{array}$ & $\begin{array}{l}\text { Children as the main target } \\
\text { in Mesatua Bali. }\end{array}$ & $\begin{array}{l}\text { Children as the main } \\
\text { target in Mesatua Bali. }\end{array}$ \\
\hline
\end{tabular}

Table 1. Comparison of the Phenomenon of Changing Aspects in the Revitalization of the Balinese Culture of Bali.

\section{A. Stimulus Analysis of Revitalization of the Balinese Mesat Culture (Desa-Kala-Patra \& Human Sense)}


At this stage the researcher conducted a stimulus analysis on the phenomenon of the revitalization of the Balinese Mesatua culture. In psychology, stimuli are referred to as part of the response stimuli that are related to behavior related to changes in the internal or external environment that can be known. When stimuli are inserted into the sensory receptor, the stimulus will affect the reflex through stimulus transduction. Stimulus aspects analyzed in this study, including; space, time, atmosphere (desa-kala-patra) and the field of the human senses based on the revitalization of the first Balinese Mesatua culture (oral), the second Mesatua Bali culture (book literature), the third period of Mesatua Bali (visual digital). The stimulus aspect of space, time and atmosphere is known as the conception of the Desa-Kala - Patra which is a concept inherited from Balinese ancestors to unite all the differences that exist on the island of Bali (culture, religion, place, ornaments, layout, etc.), and can accept the fact that in uniform there will certainly be diversity and in unity there must be differences (Figure 6). So that Balinese will not be aprioris in seeing the problems faced, but will try to see the phenomenon or problem from the aspects of the village (place), time (time), patra (atmosphere) that is, where the problem or phenomenon occurs, when the problem or phenomenon arises, and who are the subjects involved and related to handling the problem.

1) Desa Stimulus (space) in the Mesatua Bali Culture desa (space), on the stimulus of human behavior has a space of freedom to think and choose. By choosing what response you want to give to the stimulus received. With this freedom of choice, humans can create a response that has a positive impact that does not harm both parties. The end is getting used to giving space to choose to create synergy. In the Balinese Mesatua culture the first (oral) period of space became the main choice that must be determined, Mesatua Bali orally is usually done in confinement or bedroom in a residential environment. Where in that room the parents and their children carry out the activities of the Mesatua Bali. The desa (space) determines the conveyance with either fairy tales (satua) or songs that are chanted. In the Mesatua Bali Bali the second period (writing literature) still made space the first choice, but space in this period developed in addition to the sleeping space there was also a study room and school environment became the main space, with the existence of satua books in the second period made children can read it at home, at school or in the library. In the third period of the Bali Mesat Culture (visual digital) it can be said that space is not an option, this is because the Balinese Mesatua culture that has been visualized can be accessed easily and anywhere just by using a mobile phone.

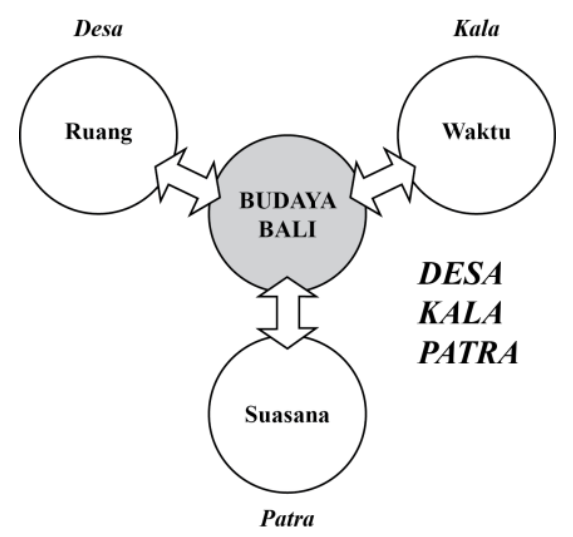

Figure 6. Photograph image of Schema Desa-Kala-Patra

It can be seen and felt very clearly, the difference in the use of the desa (space) from each period of the Mesatua Bali culture. Starting from period I (oral), house, garden and bed as a peting aspect in the desa (space). In period II (literature), the desa (space) is reached or utilized more widely and increases outside the home environment such as schools, libraries, bookstores and so on. The desa (space) that can be said to be unlimited occurs in period III (digital visual), where the actors and target audience are no longer limited by the desa (space) in Mesatua Bali. 
This is thanks to Mesatua Bali activities that are easily accessible on Instagram social media through their respective mobile internet and smartphone access.

2) Stimulus Kala (time) in the Mesatua Bali Culture kala (time), Many parents who complained could not be Mesatua Bali, especially with an attractive style. The feeling of not being able to do and busy the old man makes one of the causes of the Mesatua Bali rarely done either at the time of bedtime or at any time. Though Mesatua Bali has many benefits for children. Mesatua Bali has a strong effect on children's emotional development. It may be difficult for parents to find time with children. However, the time of Mesatua Bali can play an important role in forming a strong inner bond between children and parents.

In the first period of Balinese Mesatua (oral) culture, Mesatua Bali is often carried out at night by parents to their children as sleepers and also the attainment of very thick moral messages contained in every story in Mesatua Bali in the Mesatua way Bali is a unique and interesting moral message and these norms are well received by children. However, with the limitations of the ability and time of parents to Mesatua Bali in the second period of the Mesatua Bali culture (book literature), the children began to study and could read for themselves satua-satua bali which was published in school books. With the current technological developments in Mesatua Bali in the third period (digital visual), it is increasingly easy to do and access wherever and whenever without being limited by the time of morning, afternoon or night, all of which can be accessed through Instagram social media which must be supported by good internet connection. 3) Stimulus Patra (atmosphere) Mesatua Bali Culture Patra (atmosphere), when sitting in elementary school is a phase where children are expected to be able to interact socially with the environment. Stories of friendship in Mesatua Bali are very useful to help children be able to establish relationships with peers. Children will start thinking logical things at this age. Children have been able to connect the cause and effect of an event.

Mesatua Bali verbally in the first period is very well known for its uniqueness which is not monotonous with a flat voice. But by being expressive and using gestures so that children will be interested in listening to the satua (fairy tales) that are delivered. Bali will not be interesting if children are still playing or joking. The message to be conveyed contained in a fairy tale will not reach the minds of children. Because he is still concentrated in other activities. The atmosphere in ancient times can be said to be quieter and can be felt a mystical aura of a dim atmosphere with illuminating incandescent lights giving the impression in every corner of the surrounding space at the time of Mesatua Bali at night. This is what can grow the imagination of children as an audience.

Likewise, the atmosphere of calm needed in the second period of Balinese culture (book literature) in understanding the one and only content in a book requires high concentration to be able to imagine and imagine what the contents, ideas, and messages contained in each of Bali's elements. The priority of the atmosphere of tranquility is very influential on Mesatua Bali in the third period (visual digital) because it can be done anywhere and anytime just by being presented with pictures of children as audiences can understand the characters, along with the contents of the stories or visual images) Mesatua Bali. However, in the third period this can reduce social interaction between parents and children who should be able to bring up the imagination, but on the contrary what emerges is a different understanding of the target audience.

4) Human Sense in the Mesatua Bali Culture. The field of the human senses is 5 (five), the senses or senses of an interface, contact between souls in the form of a spiritual self-awareness with environmental material. The five types of sensory functions as sensors in Sanskrit are called the five senses and in Indonesia better known as the five senses namely; Helper tool for viewing (eyes), a helper for hearing (ears), and, a helper for feeling (skin / sense of touch) that is very influential on the stimulus of Mesatua Bali culture, while a tool for tasting (tongue), a tool to help (nose) can be said to have no stimulus effect on Balinese Mesatua culture.

The senses of the first human being that greatly influences the stimulus are the sense of hearing (ears). The ear is an organ that is able to detect, recognize sounds and also a greater role in balance and body position. In the Balinese Mesatua culture the first (oral) period of hearing 
became the first stimulus to receive it. This happened when the parents of Mesatua Bali verbally with narratives, intonations and songs, where the children's situmulus hearing (ears) caught the sound was sung by parents in Mesatua Bali. Sound in this case is a form of energy that moves through air, water, or other objects, in a wave. Although the ear detects sound, recognition and interpretation of functions are carried out in the brain and central nervous system. Sound stimuli are delivered to the brain via nerves that connect the ear and brain (vestibulococcal nerve) with this can create imagination in the human brain. Likewise, the second Balinese culture of the second period (book literature) of the sense of hearing (ears) still captures the stimulus when a teacher reads a single book to students at school. Whereas in the third period of Bali (digital visual), the sense of hearing barely captured the stimulus because of the absence of sound sources that emerged in the third period of Bali's Balinese culture (digital visual).

Seer senses (eyes) are visual organs that detect light. Simple eyes do nothing but only determine whether the environment is bright or dark. More complex eyes are used to give a visual feeling. In Balinese Mesatua culture the first (verbal) period of the dominant seer senses is used to see the interactions and expressions of the parents when delivering oral narratives. The seer senses (eyes) are more likely to be utilized in the second period of the Balinese Mesatua culture (book literature), where the eyes are allocated to be able to read the writings in the satua bali book. Likewise in the third period of the Balinese Mesatua (visual digital) the stimulus of the visual senses is needed in seeing the visuals in the pictorial stories (comics) displayed. While Indera Peraba (skin) which is a feeling of touch. In the skin are nerve endings from touch. Not all skin surfaces are tools that are sensitive touchers. The most sensitive parts are fingertips and lips. The skin can distinguish coarse, fine, etc. The sense of Peraba (skin) is more likely to be obtained by the stimulus in the second period of Balinese Mesatua culture (book literature) where the skin can feel the texture of the gauze or the smoothness of Balinese satua books that are held and can be read. Under this, researchers present graphic stimulus comparisons and indicators of change phenomena in the revitalization of Balinese Mesatua culture (see Figure 7 aand Table 2).

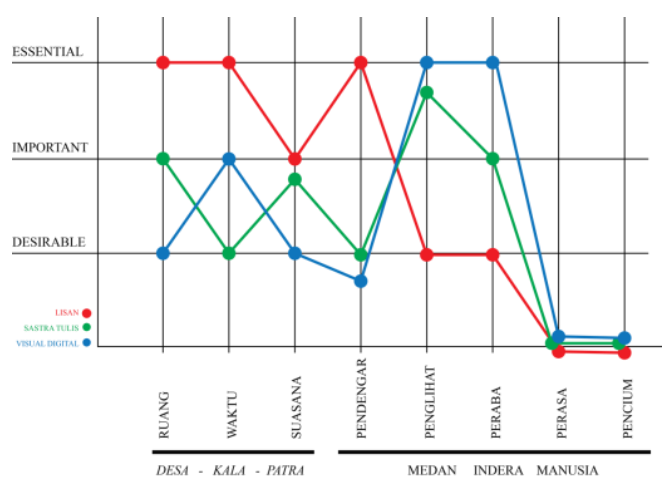

Figure 7. Photograph image of Balinese Stimulus Culture Comparison Char

\section{B. Analysis of Visual Design of the Revitalization of Bali's Mesatua}

The existence of art and culture in Bali which has a wide variety of special forms in the field of art, one of which is pre-art art. According to Suardana (2001) Prasi art is an image and text that is written on palm leaves by using a small knife with a pointed tip (pengutik, Bali), then given a black color made from baked candlenut. Prasi art that developed in Bali was made on full palm leaves written (text) without any pictures, and lontar which was full of pictures (the whole picture without text) and lontar containing writings and pictures [18] (igure 9 and $\underline{10})$. 


\begin{tabular}{|c|c|c|c|}
\hline INDICATOR & STORYTELLING & $\begin{array}{c}\text { WRITING } \\
\text { LITERATURE }\end{array}$ & $\begin{array}{l}\text { VISUAL } \\
\text { DIGITAL }\end{array}$ \\
\hline What's new & $\begin{array}{l}\text { Mesatua Bali as an oral } \\
\text { culture can be enjoyed at } \\
\text { home. }\end{array}$ & $\begin{array}{l}\text { Mesatua Bali as a written } \\
\text { literary work can be enjoyed } \\
\text { at school or in the library. }\end{array}$ & $\begin{array}{l}\text { Mesatua Bali in } \\
\text { digital visuals can be } \\
\text { accessed anywhere. }\end{array}$ \\
\hline What changed & $\begin{array}{l}\text { The auditory senses (ears) as } \\
\text { the main stimulus for the } \\
\text { sound. }\end{array}$ & $\begin{array}{l}\text { Indra Pengawasan (eyes) as } \\
\text { the main stimulus for } \\
\text { writing. }\end{array}$ & $\begin{array}{l}\text { Indra Vision (eyes) as } \\
\text { the main visual } \\
\text { stimulus catcher. }\end{array}$ \\
\hline $\begin{array}{l}\text { What is } \\
\text { missing }\end{array}$ & $\begin{array}{l}\text { Space, time and atmosphere } \\
\text { (desa-kala-patra) at home at } \\
\text { night with family. }\end{array}$ & $\begin{array}{l}\text { Space, time and atmosphere } \\
\text { (desa-kala-patra) at school } \\
\text { during the day with friends. }\end{array}$ & $\begin{array}{l}\text { Space, time and } \\
\text { atmosphere (desa- } \\
\text { kala-patra) wherever } \\
\text { and whenever. }\end{array}$ \\
\hline What's fixed & $\begin{array}{l}\text { Children as the main target } \\
\text { in Mesatua Bali. }\end{array}$ & $\begin{array}{l}\text { Children as the main target } \\
\text { in Mesatua Bali. }\end{array}$ & $\begin{array}{l}\text { Children as the main } \\
\text { target in Mesatua } \\
\text { Bali. }\end{array}$ \\
\hline
\end{tabular}

Table 2. Comparison of the Phenomenon of Stimulus Changes in the Revitalization of the Balinese Culture of Bali

In Bali the tradition of writing and copying manuscripts on palm leaves had developed at the end of the XV century in the era of the Gelgel kingdom, after the entry of Majapahit influence into Bali. At that time the king in power in Gelgel was Dalem Watu Renggong. After the center of the kingdom moved to Klungkung at the beginning of the eighteenth century, many texts in the form of kekawin and kidung were composed in the form of "Geguritan or Parikan" (Balinese literary works formed by pupuh-pupuh / tembang verses), as well as the field of art i.e. the image is contained in ancient manuscripts made from palm leaves, which are scratched with a screwdriver, then colored with candlenut [19] (Figure 8)

Talking about visual problems, in this case is the form or form itself that can be seen in a real way (visualization of forms), forms in art are also called visual languages, forms of storytelling, the intended form is a form or form of an object, tangible objects in dwimatra and trimatra, so that in the dwimatra visual language and the tridimensional visual language its form appears. A work in the form of an image is a visualization of the visible form. Images that appear in a relatively flat field are usually in the form of sketches, drawings, paintings, photographs, graphics, reliefs, widescreen displays, kca screens (TV), monitor screens (computers) and so on [20]

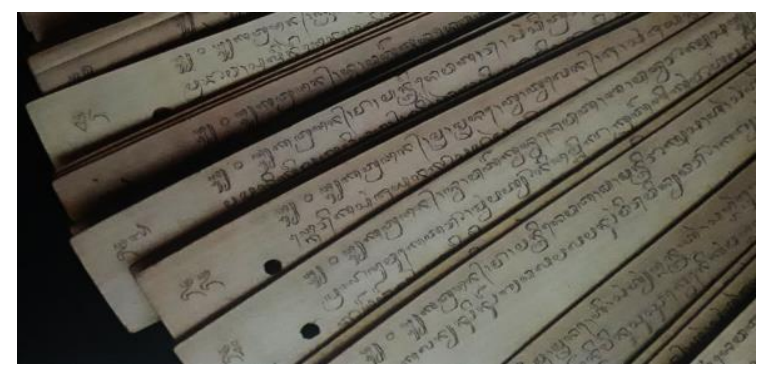

Figure 8. Photograph image of Throwing Balinese Script Posts Source: Harmoko, 1997:16 [22] 


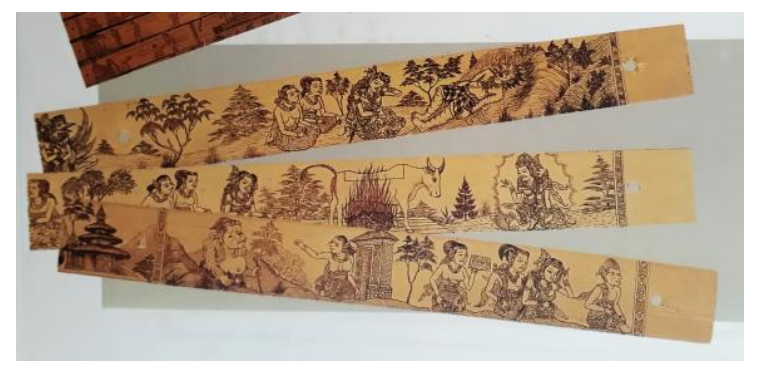

Figure 9. Photograph image of Balinese Lontar Picture Source: Gallop, 2002:4 [21].

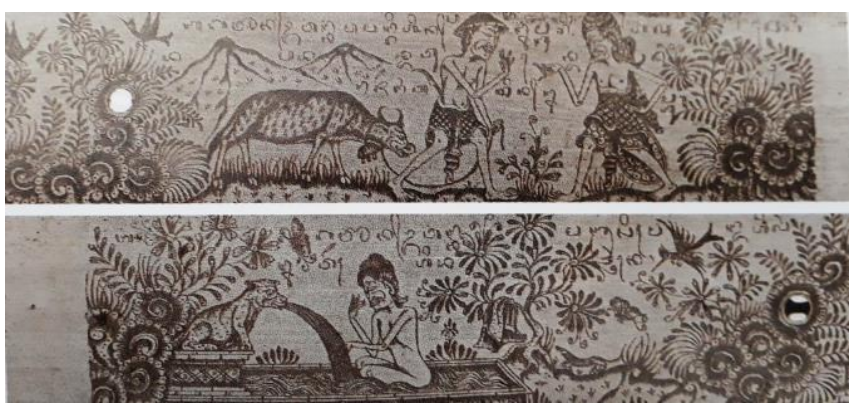

Figure 10. Photograph image of Picture Throwing - Reads Balinese Script. Source: Gallop,2002:40 [21]

Through an analysis that has been done previously from the 3 periods starting from the first Balinese (oral) Mesatua culture, the second period of Mesatua Bali (book literature), the third period of Mesatua Bali (visual digital), the researchers found 3 illustrations that had the same story, but with different drawing styles. Therefore, the researchers chose the 3 illustrations to compare with the style of Balinese visual depiction, namely Prasi Wayang Art on palm leaves (Figure 11). This is done to find out the phenomenon of changes that occur.

The illustrations taken have the same scene with the story as follows; "Where at one time the Tiger was scared to see the figure of the Goat tricking him with his horns and words. That made the Tigers panic and make him run away with his tail which is still tied to the monkey".
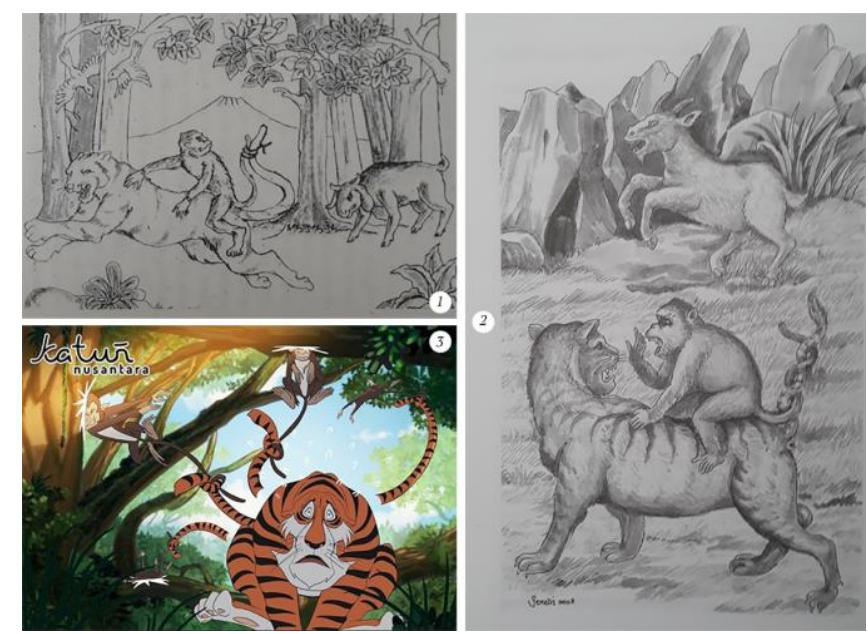

Figure 11. Photograph image of Comparison 3 Illustration of Satua Bali "Kambing Takutin Macan" 
Selected illustration scene (one) is one of the illustrated works found in the Satua Bali book "Kambing Takutin Macant" written by I.N.K. Suparta in 2010. Of the 5 illustrations in one unit, one (1) illustration was chosen that had the same scene as the other satua source. In this book it can be seen that the application of more text and illustrations (visual) as support on each page. Visual portrayals of selected illustrations (one) It seems clear that you still hold tightly to the Balinese visual style that highlights its multiplicity. Starting from the visual depiction of characters from Tigers, Monkeys, Goats that are pictured realistically. Likewise with the depiction of the background starting from trees, mountains until the birds are drawn in reaslis which has a distinctive style of Balinese visual images found in the prasi art of puppets inscribed on palm leaves.

Changes in visual style began to be seen in the scene of the second choice illustration (two) found in the book Tantri Stories written by Made Taro in 2015. The illustrations in the book were made in portrait format on a full page. In contrast to the book reviewed previously which has 5 (five) illustrations, while in the book by Made Taro it has 1 (one) illustration in each title of the unit as a supporter in the delivery of cheers with written stories (text) (Figure 12). The visual style of this illustration, although it still looks like an illustration in a previous book, is still a lot of Balinese visual style that is left behind and not stated in the choice illustration II (two) (Figure 13). Realistic portrayals have begun to look different as well as the shading technique, but in terms of coloring still apply dark-black and white light coloring in each character and object that is applied.

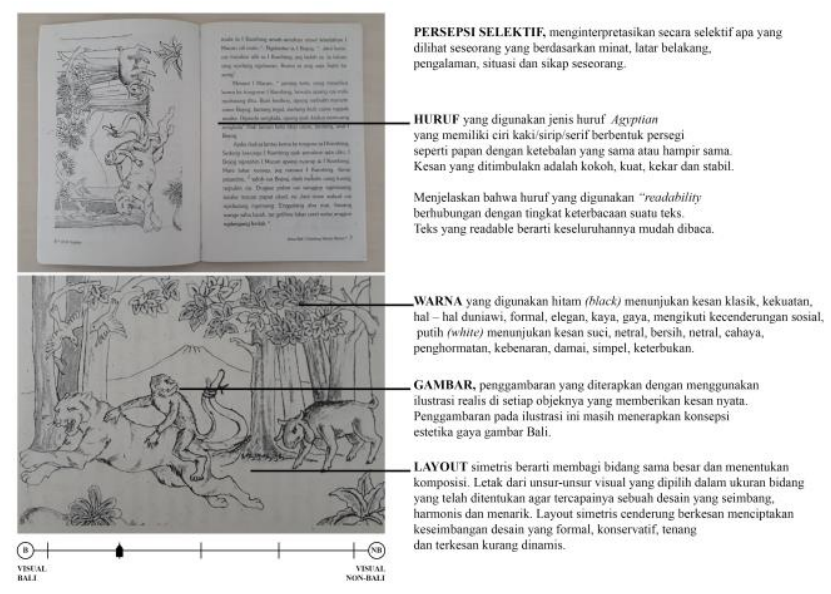

Figure 12. Photograph image of Illustration I Satua Bali "Kambing Takutin Macan"

Changes and differences in the depiction of satua Bali illustrations are increasingly apparent in the illustration of choice III (three) (Figure 14). This illustration is a visual work adapted from Satua Bali "Tiger Takutin Goats" by the Katur Nusantara Community into a pictorial story work with the title "Goat Ingenuity" a visual element of multiplicity characterized by nonexistent realist style seen even applied to this illustrated work, this style of visual depiction tends to be more of a western image style that prioritizes character expressions. However, unique to this illustration, it is depicted as if telling a story with a RWD (space-time-flat) system, seen depicting monkeys and tigers drawn dynamically and repeatedly, indicating movement in this illustration. This illustration is drawn in full on one page with added storyline in the form of writing (text) as a supporter. 


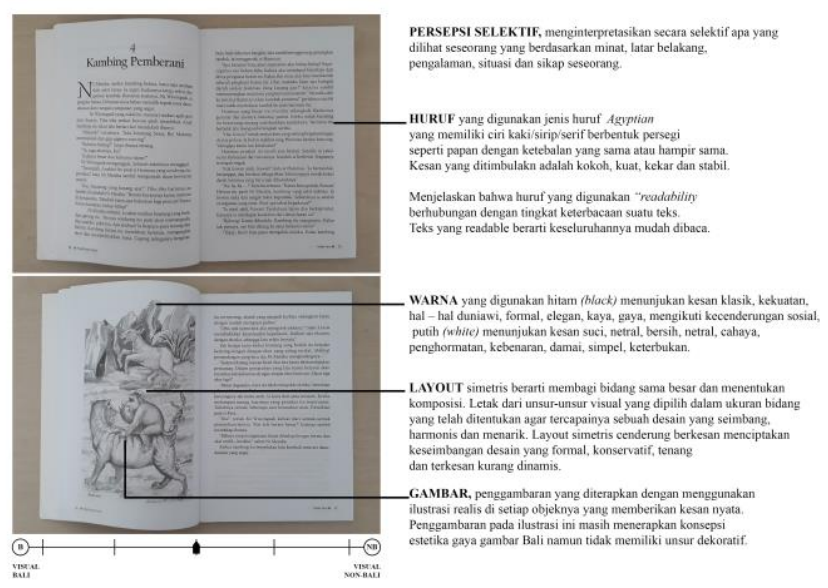

Figure 13. Photograph image of Illustration II Satua Bali “Kambing Takutin Macan"

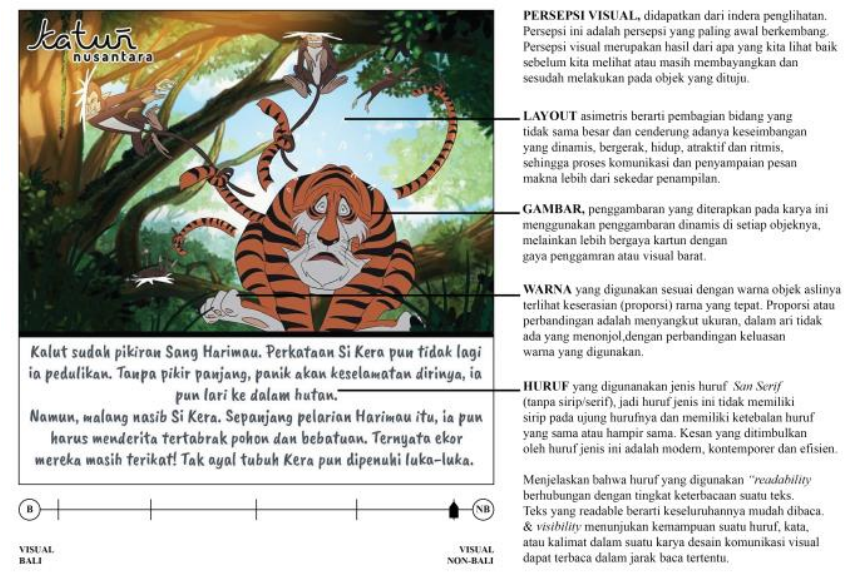

Figure 14. Photograph image of Illustration III Satua Bali "Kambing Takutin Macan”

In contrast to the previous 2 illustrations where visuals are supporting the text, so the drawers in the previous illustrations were drawn as dead images (still pictures) better known as the NPM system (naturalist - perspective - hospitalized moment), where everything is based on what the human eye sees. The following is a comparison chart from the results of a visual design analysis of the revitalization of Bali's first period (oral) culture, the second period of Mesatua Bali culture (book literature), the third period of Mesatua Bali (visual digital) based on the time period by identifying based on visual elements including; pictures, letters, colors and layouts. Then it is compared based on each of the selected illustrations with the same scene along with the period, with 3 (three) levels of values, namely, essential, important, and desirable, and equipped with an indicator table for the phenomenon of change (Figure 15 and Table 3 ).

Revitalization of the Bali Mesatua Culture Learning from history and the environment and responding to what was felt to the identified Mesatua Bali culture, and experiencing the ups and downs of cultural contestation as a result of the mobilization of its people, has encouraged its host to revitalize its culture amid the hustle and bustle of cultural heterogeneity. The cultural revitalization efforts are not easy, because they have to deal with a variety of cultural stigmas that are being drawn. This is where the Balinese people must demonstrate their ability to renegotiate the position of the Mestua Bali culture, carry out resistance by raising awareness of the entire community. The step of revitalizing the Mesatua Bali cultural tradition is basically a preservation effort between traditions in the context that has long been a tradition in the present 
context. In other word it is an act of reviving a thing that was previously powerless to be important, or some part is maintained and others are actualized so that it is different from the old form.

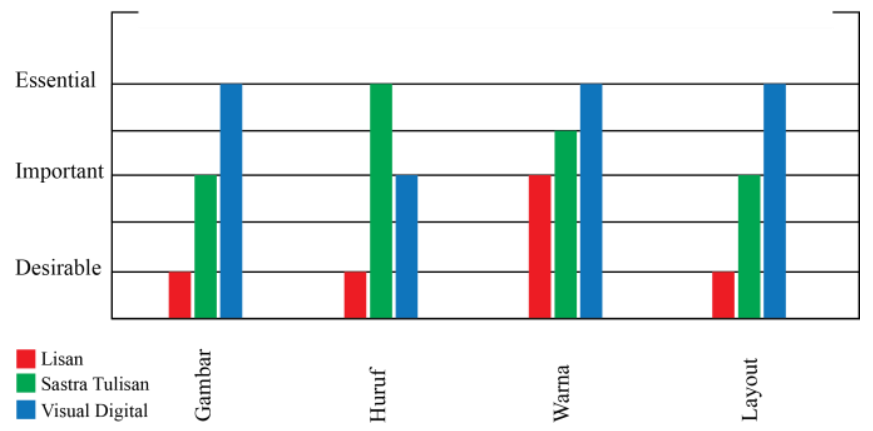

Figure 15. Photograph image of Visual Design Comparison Chart

Revitalizing the traditions of the Mesatua Bali in the midst of the diversity of forms of reaffirmation as a 'sign' that distinguishes from other cultures is reflected in the Mesatua Bali culture that is poured into the digital media as it is today. Mesatua Bali is still a part of cultural traditions, history and historical products from the individual and collective experiences of Balinese people created (recreated) as reflections expressed at the same time projected. This means that it is still preserving the past that is considered appropriate, re-entering past history into a new tradition, so that the characteristics of the Balinese culture of Bali as local wisdom become very varied and not crushed by the times.

\begin{tabular}{|c|c|c|c|}
\hline INDICATOR & STORYTELLING & $\begin{array}{l}\text { WRITING } \\
\text { LITERATURE }\end{array}$ & VISUAL DIGITAL \\
\hline What's new & $\begin{array}{l}\text { Mesatua Bali as an oral } \\
\text { culture presented with } \\
\text { narration and songs. }\end{array}$ & $\begin{array}{l}\text { Mesatua Bali as written } \\
\text { literature is delivered with text } \\
\text { and supported by images. }\end{array}$ & $\begin{array}{l}\text { Mesatua Bali in digital } \\
\text { visuals is presented in } \\
\text { illustrated and text- } \\
\text { supported stories. }\end{array}$ \\
\hline What changed & $\begin{array}{l}\text { Mesatua Bali as an oral } \\
\text { culture. }\end{array}$ & $\begin{array}{l}\text { Mesatua Bali as a literary } \\
\text { culture of writing. }\end{array}$ & $\begin{array}{l}\text { Mesatua Bali as a visual } \\
\text { culture. }\end{array}$ \\
\hline $\begin{array}{l}\text { What is } \\
\text { missing }\end{array}$ & $\begin{array}{l}\text { Submission through } \\
\text { oral narratives that give } \\
\text { rise to imagination. }\end{array}$ & $\begin{array}{l}\text { Read the contents of the } \\
\text { writing on the book without } \\
\text { having to listen to oral } \\
\text { narratives. }\end{array}$ & $\begin{array}{l}\text { Submission through } \\
\text { narrative and style of } \\
\text { visual depiction of Bali. }\end{array}$ \\
\hline What's fixed & $\begin{array}{l}\text { Imagination as a visual } \\
\text { creation in mind. }\end{array}$ & $\begin{array}{l}\text { Imagination as a visual } \\
\text { creation in mind. }\end{array}$ & $\begin{array}{l}\text { Imagination as a visual } \\
\text { creation in mind. }\end{array}$ \\
\hline
\end{tabular}

Table 3. Comparison of the Phenomenon of Stimulus Changes in the Revitalization of the Balinese Culture of Bali

The most important thing in understanding cultural diversity as production and reproduction is in the process, namely formalization, ritualization, and characterization that refers to the past. Perhaps, for the older generation, the revitalization of local culture is not necessarily acceptable, so the process of adaptation is still ongoing, because it evokes the values of Mesatua Bali culture is a response to the dynamics of cultural diversity that develops, as well as the process of 
reformulating self-identity and strategies to deal with changes philosophical and historical value.

\section{CONCLUSION}

Based on the results of the study it can be concluded that, the results of research on the revitalization of the Mesatua Bali culture are divided into 3 (three) periods, namely: the first Balinese Mesatua culture (oral), the second Mesatua Bali culture (book literature, 1993 -2017), Mesatua The third period of Bali (visual digital, 2017-2018) which has various phenomena of change in each period and event. The existence of aspects underlying the changes that occurred in the revitalization of the Balinese Mesatua period 1,2 and 3, including the following:

a) Actors (maker), at each event of revitalization of the Mesatua Bali culture starting from the first event (oral-literary writing), events II (literary writing - visual digital), and events III (digital visuals) have their respective roles. Changes in actors in each period and events give a different impression on the Balinese Mesatua culture.

b) Technology, at every event of revitalization of the Mesatua Bali culture starting from event I (oral-literary writing), event II (literary writing - visual digital), and event III (oral - visual digital) provide various developments in each event and its period begins by conveying with the narrative, then can be read, so that it can be seen with a visual display of storytelling images.

c) Target (audience), because humans are creatures that can not be separated from all forms of change that greatly support their lives, both their needs (need) or desire (will). In the context of revitalizing the Mesatua Bali culture, humans have an appetite for adjustment in the Messatua of Bali which is influenced by their culture (lifestyle), these tastes will continue to change and develop over time.

Revitalizing the Mesatua Bali culture, besides influencing by several aspects of actors, technology and targe also influences the stimulus produced from the Desa-Kala-Patra (space, time, atmosphere) and the human sensory field known as the five senses namely; Helper tool for viewing (eyes), a helper for hearing (ears), and, a helper for feeling (skin / sense of touch) that is very influential on the stimulus of Mesatua Bali culture, while a tool for tasting (tongue), a tool to help (nose) can be said to have no stimulus effect on Balinese Mesatua culture.

From the results of the visual design analysis based on the revitalization of the Mesatua Bali culture which is divided into 3 (three) periods, namely: the first Balinese (oral) Mesatua culture, the second Mesatua Bali culture (book literature, 1993-2017), Mesatua Bali third period ( digital visuals, 2017-2018) changes in image style are very clear. Where in Bali is famous for its distinctive painting style, its development is currently very different, it is clearly seen that illustrators and designers today as makers have not been able and able to produce illustrative works with Balinese style images that have an aesthetic concept Bali which was imbued with Hinduism gave birth to a culture that was vertical and horizontal. Vertical as intended is culture as an offering based on holy intentions and non-show off attitude, which implies moral messages that are presented through beauty in terms of classical aesthetic ideals. Horizontal is intended to provide enjoyment to all people and is open to outside culture. The strong foundation of conception and the norms of classical aesthetic behavior requires that Balinese people are always adaptive to outside culture to enrich their identity.

Through the analysis carried out in this study, namely, analyzing the principle of totality and value principles carried out to dissect all aspects that exist in a design phenomenon and time principle analysis to analyze changes that occur in a design based on time, there are several important things to understand by an illustrator and designer at work To always pay attention to and maintain the distinctive characteristics of a culture in the choice of development decisions of a form or facility, so as to avoid the possible impacts that can occur, both for the target (audience) and the (maker). As a manifestation of maintaining the continuity of tradition well, there must be an increase in the understanding and sensitivity of the makers of the aesthetics of 
Bali in the preservation of the Mesatua Bali culture in a visual form that will be able to filter the influence of visual and Western aesthetics.

\section{ACKNOWLEDGMENT}

The author thanks Dr. Ahadiat Joedawinata, who has been willing to spend time, energy and thought to direct the author in completing this research.

\section{REFERENCES}

[1] Hobsbowm, Eric \& Terence, Ranger. 1992. The Invention of Tradition. Cambrige University Press

[2] Margaretha, Risma. 2017. Revitalisasi Budaya: Strategis Identitas Etnik Lampung. Yogyakarta: Suluh Media

[3] Ode, Samsul. 2015. Budaya Lokal sebagai Media Resolusi dan Pengendalian Konflik di Provinsi Maluku (Kajian, Tantangan, dan Revitalisasi Budaya Pela). POLITIKA, Vol. 6, No.2, Oktober 2015 halaman 93-100.

[4] Mufid, A. Syafi'i. 2010. Revitalisasi Kearifan Lokal dalam Pemberdayaan Masyarakat. Harmoni - Jurnal Multikultural \& Multireligius Vol. IX No. 34 halaman 83-92.

[5] Amirrachman, Alpha (ed.). 2007. Revitalisasi Kearifan Lokal: Studi Resolusi Konflik di Kalimantan Barat, Maluku dan Poso. Jakarta: ICIP.

[6] Azra, Azyumardi. 2002. Paradigma Baru Pendidikan Nasional Rekonstruksi dan Demokratisasi. Jakarta: PT. Kompas Media Nusantara.

[7] Suarjana, Nyoman. 1994. Cerita I Lubdaka. Bali: CV. Kayumas Agung.

[8] Pratama, I. TA: Penciptaan Buku Pop-up Mesatua Bali Berjudul" I Lubdhaka" Dengan Teknik Pull Tab Sebagai Upaya Pelestarian Budaya Tradisional. Diss. Institut Bisnis dan Informatika Stikom Surabaya, 2015.

[9] Danandjaja, James. 1984. Folklor Indonesia : Ilmu Gosip, dongeng, dan lain-lain. Jakarta : Pustaka Utama Grafiti.

[10] Rohendi Rohidi, Tjetjep. 2011. Metode Penelitian Seni. Semarang: Cipta Prima Nusantara

[11] Sugiyono. Metode Penelitian Kuantitatif Kualitatif Dan R \& D. Bandung: Alfabeta. 2014.

[12] Sukmadinata, Nana Syaodih. 2005. Metode Penelitian Pendidikan. Bandung: Remaja Rosda Karya.

[13] Danim, Sudarwan. 2000. Metode Penelitian untuk Ilmu-ilmu Perilaku. Jakarta. Bumi Aksara.

[14] Denzin, Norman K. dan Yvonna S. Lincoln (eds.). 2009. Handbook of Qualitative. Research. Terj. Dariyatno dkk. Jogjakarta: Pustaka Pelajar.

[15] Sachari, Agus. 2005. Metodologi Penelitian Budaya Rupa. Penerbit Erlangga.

[16] Joedawinata, Ahadiat. 2017. Desain Dalam Konteks Praktis Utiliter, Estetika dan Simbolik. Materi Kuliah Estetika Dalam Desain. Magister Desain UNIKOM Bandung.

[17] Pratama, I. Gede Yudha. Aesthetics Study of Mesatua Bali Culture in Digital Media. International Conference on Business, Economic, Social Science and Humanities (ICOBEST 2018). Atlantis Press, 2018.

[18] Widia, Wayan. 1987. Data Tertua Mengenai Seni Lukis Bali: Tinjauan Tema dan Gaya, Estetika Dalam Arkeologi. Pusat Penelitian Arkeologi Nasional.

[19] Suardana, I. Wayan. Studi Komparatif Gambar \& Tulisan Seni Prasi Wayang Dengan Komik Cerita Wayang Klasik dii Indonesia. Program Seni Rupa \& Desain Program Pascasarjana Institut Teknologi Bandung, 2001. 
[20] Tabrani, Primadi. 2000. Proses kreasi-Gambar Anak-Proses Belajar. Bandung: Penerbit ITB.

[21] Gallop, A.T. 2002. INDONESIAN HERITAGE: Seni Rupa - Seni Pernaskahan. Jakarta: Buku Antar Bangsa.

[22] Harmoko.H. 1997. INDONESIAN INDAH: Aksara. Jakarta: Yayasan Harapan Kita 